\title{
A River Flood and Earthquake Risk Assessment of Railway Assets along the Belt and Road
}

\author{
Qianzhi Wang $^{1,2} \cdot$ Kai Liu $^{1,2} \cdot$ Ming Wang ${ }^{1,2}$. Elco E. Koks ${ }^{3}$
}

Accepted: 9 May 2021 / Published online: 11 June 2021

(C) The Author(s) 2021

\begin{abstract}
Mitigating the disaster risk of transportation infrastructure networks along the Belt and Road is crucial to realizing the area's high trade potential in the future. This study assessed the exposure and risk of existing and planned railway assets to river flooding and earthquakes. We found that about $9.3 \%$ of these railway assets are exposed to a one in 100 year flood event, and $22.3 \%$ are exposed to a one in 475 year earthquake event. The combined flood and earthquake risk of physical damage to railway assets, expressed by expected annual damage (EAD), is estimated at USD 1438 (between 966 and 2026) million. Floods contribute the majority of the risk (96\%). China has the highest EAD for both floods and earthquakes (between USD 240 and 525 million in total). Laos and Cambodia are the countries with the highest EAD per km from flooding (USD 66,125-112,154 and USD 31,954-56,844 per $\mathrm{km}$, respectively), while Italy and Myanmar have the highest EAD per km from earthquakes (USD 1000-3057 and USD 893-3019 per km, respectively). For the newly built and planned projects along the Belt and Road, the EAD is estimated at USD 271 (between 205 and 357) million. The China-Indochina Peninsula Economic Corridor and China-Pakistan Economic
\end{abstract}

Kai Liu

liukai@bnu.edu.cn

1 State Key Laboratory of Earth Surface Processes and Resource Ecology, Beijing Normal University, Beijing 100875, China

2 Academy of Disaster Reduction and Emergency Management, Faculty of Geographical Science, Beijing Normal University, Beijing 100875, China

3 Institute for Environmental Studies (IVM), Vrije Universiteit Amsterdam, $1081 \mathrm{HV}$ Amsterdam, Netherlands
Corridor have the highest absolute EAD and EAD per km, with EADs reaching USD 95 and USD 67 million, and USD 18 and USD 17 thousand per $\mathrm{km}$, on average, respectively. For railway segments with high risks, we found that if the required adaptation cost within 20 years to realize a $10 \%$ increase of the railway quality is below $8.4 \%$ of the replacement cost, the benefits are positive.

Keywords Belt and Road C Cost-benefit analysis · Disaster risk · Railway assets

\section{Introduction}

The Belt and Road Initiative (BRI), initially announced in 2013, aims to promote connectivity and cooperation among countries in Asia, Africa, and Europe (Yu et al. 2018). As of the end of April 2021, the BRI spanned approximately 146 countries. Transportation connectivity is a critical priority for the implementation of the BRI. Refinitiv's Belt and Road Initiative database (Refinitiv 2020) indicates that, by the first quarter of 2020, transportation infrastructure investment amounted to USD 1888 billion, accounting for $47 \%$ of the total investment in the BRI. However, natural hazards and disasters along the Belt and Road (B\&R) are widely distributed and occur frequently, accounting for $68.07 \%$ of global disaster occurrences (Chai et al. 2020). In March 2014, for example, heavy rainfall caused serious damages to the road construction project in Pakistan, which resulted in losses of USD 0.3 million (PICC 2014).

Several studies have investigated the disaster risks faced by the $\mathrm{B} \& \mathrm{R}$ countries, but have done so primarily at the country level (Cui et al. 2017; Helsingsen et al. 2018; Wang et al. 2018; World Bank 2019; Wu 2019; Chai et al. 2020; Khan et al. 2020; Yu et al. 2020), and with no focus 
on the physical damage to assets. Yu et al. (2020) estimated the risk of floods, droughts, and convective storms along the Silk Road Economic Belt in China, the Philippines, and Vietnam, expressed by the exceeding probability of relative losses. Chai et al. (2020) explored the coupled effect of factors that influence disaster occurrences and losses in the $\mathrm{B} \& \mathrm{R}$ countries. The results reveal that disaster frequency and socioeconomic development levels directly impact economic loss, death toll, and population, while ecological development through its influence on disaster frequency indirectly impacts them. Wang et al. (2018) assessed the losses to some of the B\&R countries caused by 2014 Typhoon Rammasun, based on a multiregional input-output model. The study estimated a total of USD 85 million of economic losses and identified the most affected industries, including manufacturing, agriculture, and forestry. Regarding the disaster risks faced by transportation infrastructures along the $\mathrm{B} \& \mathrm{R}$, most existing studies focus on case studies. Helsingsen et al. (2018) qualitatively assessed the high/median/low flood risk of the North-South Road Corridor and East-West Road Corridor of Myanmar. Cui et al. (2017) provided a regional-scale risk assessment for the China-Pakistan Highway, and the risk levels of each segment were determined by combining hazards based on expert judgment and vulnerability analysis.

However, there is still a lack of large-scale, crosscountry quantitative risk assessments for the B\&R transportation infrastructure, which is important for policy planning and risk transfer. In this study, we aim to assess the risk to railway infrastructure in the $\mathrm{B} \& \mathrm{R}$ areas subject to earthquakes and river flooding, the two major disasters faced by B\&R countries. We first collected the data for existing and planned railway assets, including geographical information, specific characteristics of railway transport routes, and the economies along the routes. Next, we assessed the risks by combining the hazard map of river flooding and earthquakes with railway exposure and vulnerability, where the risk is expressed in terms of Expected Annual Damage (EAD). Finally, based on the risk assessment results, we performed a cost-benefit analysis (CBA) of adaptation measures, which shows that more positive net present value (NPV) results occur in segments with higher risks.

\section{Materials and Methods}

In this section, we first introduce the data sources used, including the B\&R railway distribution and hazard map, and then present the research framework. On this basis, the methods used are presented in detail, including exposure and risk calculation and cost-benefit analysis of risk adaptation.

\subsection{Data}

In this section, we first present the spatial distribution of $\mathrm{B} \& \mathrm{R}$ railway lines. Then we describe in detail the hazard data used in the study, including the flood hazard map, the seismic hazard map, and the liquefaction susceptibility map.

\subsubsection{Railway Infrastructure}

We only considered the $50 \mathrm{~B} \& \mathrm{R}$ countries that can be connected to China by railway. The railway infrastructure network was developed based on the Belt and Road Economics (World Bank 2019), the Belt and Road Panoramic Map (Xi and Liu 2017), and the Construction and Development Planning of China Railway Express (2016-2020) (NDRC and NRA 2016), as shown in Fig. 1. The locations of railway bridges along existing railway lines were extracted from OpenStreetMap. For railway lines under construction or in planning, we did not consider railway bridges due to the lack of information.

There are six economic corridors along the B\&R, connected by railway lines (Fig. 1): the China-MongoliaRussia Economic Corridor (yellow); the New Eurasian Land Bridge (red); the China-Central Asia-West Asia Economic Corridor (dark blue); the China-Indochina Peninsula Economic Corridor (green); the China-Pakistan Economic Corridor (orange); and the Bangladesh-ChinaIndia-Myanmar Economic Corridor (light blue). As calculated from Fig. 1, new projects are distributed in the China-Central Asia-West Asia Economic Corridor $(23.0 \%)$; the Bangladesh-China-India-Myanmar Economic Corridor (21.6\%); the China-Indochina Peninsula Economic Corridor (19.9\%); the China-Pakistan Economic Corridor (14.8\%); the China-Mongolia-Russia economic corridor (15.4\%); and the New Eurasian Land Bridge $(5.4 \%)$.

\subsubsection{Hazard Maps}

Floods, earthquakes, and typhoons are the three major natural hazards faced by the B\&R countries, and accounted for $89.1 \%$ of the total losses of $B \& R$ countries to natural hazards and disasters during 1900-2015 (Mao et al. 2018). As there is a lack of vulnerability functions of railway infrastructures to typhoons, we only selected floods and earthquakes for our analysis. The hazard maps were based on current data (1960-1999 for floods, 1904-2013 for earthquakes), representing the hazard level to that date.

1. Flood hazard map We used the GLOFRIS (GLObal Flood Risk with IMAGE Scenarios) global river flood hazard maps of Ward et al. (2013), Winsemius et al. 


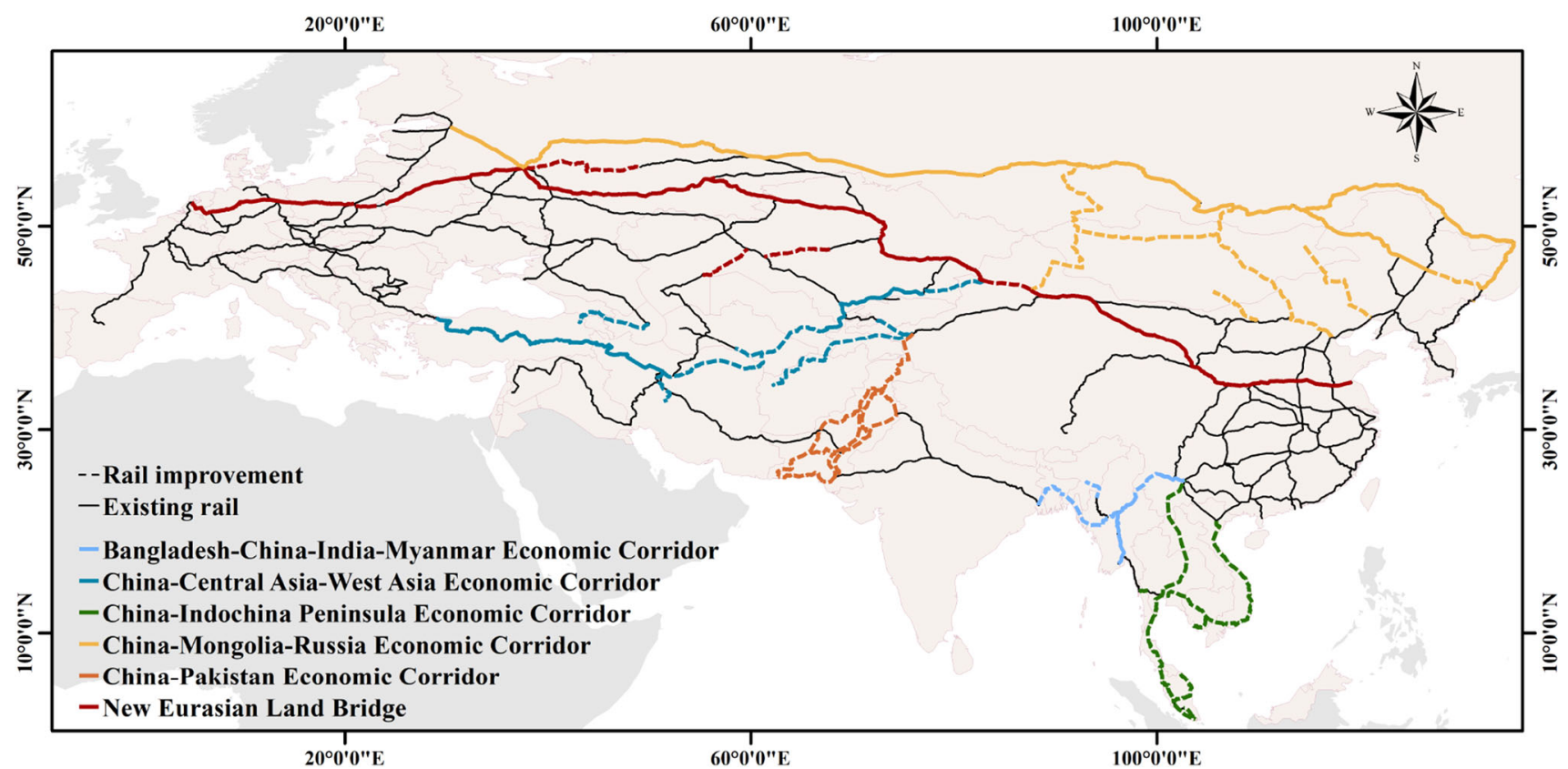

Fig. 1 Railway assets of the Belt and Road project considered in this study. Source: World Bank (2019), Xi and Liu (2017), NDRC and NRA (2016)

(2016), Ward et al. (2017) for the flood risk analysis. GLOFRIS uses a global hydrological and hydraulic model to simulate the daily discharges and flood volumes at a $0.5^{\circ} \times 0.5^{\circ}$ grid. Extreme value analysis is applied to derive the maximum flood volume of the grid, and finally, the coarse resolution flood volume is converted to the high resolution inundation depth through the GLOFRIS Downscaling Model. The flood hazard maps for nine return periods $(2,5,10,25,50$, $100,250,500$, and 1,000 years) are provided by Winsemius et al. (2013), and the resolution is 30 arcseconds (ca. $1 \mathrm{~km}$ ). The hazard map is presented in the form of the maximum expected inundation depth in meters for each grid. As it does not consider the flood protection level in different locations, we further applied the FLOPROS (FLOod PROtection Standards) database (Scussolini et al. 2016), which provides the flood protection level at the subnational scale expressed by the return period. We assumed that if the flood return period is below the flood defense level, the infrastructures will not be damaged.

2. Seismic hazard map A seismic hazard map was obtained from the GAR (UNISDR Global Assessment Report) 2015 Atlas (CIMNE and INGENIAR 2015), developed based on the probabilistic seismic hazard assessment model at the global level. Seismicity parameters are created through the seismic catalogue and smoothed seismicity technique to generate a set of stochastic event sets that contain both intensity and probability information. For each event, the ground motion prediction equations are used to generate peak ground acceleration (PGA), and seismic hazard maps are ultimately generated for different return periods. These maps provide five return periods $(250,475,975$, 1500 , and 2,475 years) expressed by PGA (in $\mathrm{cm} / \mathrm{s}^{2}$ ), and the resolution is $0.072^{\circ} \times 0.072^{\circ}$.

3. Liquefaction susceptibility map A liquefaction susceptibility map was obtained from Zorn and Koks (2019), developed based on the inland and coastal geospatial liquefaction models by Zhu et al. (2017) and a global $\mathrm{V}_{\text {S30 }}$ (30 $\mathrm{m}$ averaged shear-wave velocity) dataset (Worden et al. 2015). The liquefaction model constructs a function of liquefaction probability and explanatory variables including rivers, groundwater, precipitation, and land mass, among others. The susceptibility map provides five soil liquefaction susceptibility bands: very low, low, medium, high, very high, and the resolution is $1.2 \mathrm{~km} \times 1.2 \mathrm{~km}$.

\subsection{Methods}

Risk is usually determined by hazard, exposure, and vulnerability (Feyen et al. 2012; Bach et al. 2013; Koks et al. 2015). In this study, hazards refer to fluvial floods and earthquakes and are expressed by the intensity and probability of occurrence. Exposure refers to the railway assets exposed to these hazards, and vulnerability is represented by a vulnerability curve or matrix, which describes the relationship between the damage ratio of railway assets and 
the intensity of hazard. The research framework of this study is presented in Fig. 2. Detailed procedures of risk assessment and cost-benefit analysis are described in the following.

\subsubsection{Risk Assessment}

We overlaid the hazard map at different return periods with railway maps to obtain railway hazard exposure and risk. Expected annual exposure (EAE) was used to express railway exposure to hazard, which is defined as the sum of the exposure level multiplied by the inverse of return period, as shown in Eq. 1 (Espinet et al. 2018):

$\mathrm{EAE}=1 / 2 \sum_{i=1}^{n}\left(\frac{1}{T_{i}}-\frac{1}{T_{i+1}}\right)\left(E_{i}+E_{i+1}\right)$

where $T_{i}$ is the $i$ th return period, and $E_{i}$ is the railway exposure corresponding to $T_{i}$ with a unit of $\mathrm{km}$. The inverse of the return period is unitless and the unit of EAE is therefore the same as that of $E_{i}(\mathrm{~km})$. Railway assets are assumed not to be exposed to flood hazards and earthquake hazards when the flood depth is lower than $0.25 \mathrm{~m}$ and the PGA is smaller than $0.092 \mathrm{~g}$.

The expected annual damage (EAD) was used to represent risk, which is defined as the sum of damage ratio of each railway asset estimated by using the vulnerability curve or matrix multiplied by the inverse of return period.
For floods, the vulnerability curve of railway lines is given by the HIS-SSM2015 (De Bruijn et al. 2015) (Fig. 3a), which was derived based on expert judgment and was developed for the Netherlands. Considering the construction quality variations in different countries, we used the Railway Quality Index (RQI), which was obtained from the World Trade Congress 2017-2018 (Schwab et al. 2017), to convert the vulnerability curve of railways in the Netherlands and make it applicable to other countries. The RQI reflects regional differences in railroad quality, which can reflect the level of railway flood protection to some extent, as construction quality and maintenance level largely influence flood protection capacity. Furthermore, because the embankment or other raised railway structures are not considered in the vulnerability curve, this curve may lead to an overestimation of damage according to the HISSSM2015 (De Bruijn et al. 2015), and we converted the flood depth of each damage ratio by 0.9-1.4 times to consider the uncertainty of the vulnerability curve (The Netherlands, for example, is shown as the dotted line in Fig. 3a). Since most bridges undergo strict flood design procedures, many risk assessment frameworks, such as Hazus (Scawthorn et al. 2006) and HIS-SSM (De Bruijn et al., 2015), suggest that the probability of railway bridges sustaining flood damage is very low, and we ignore bridge damage from floods in this study.

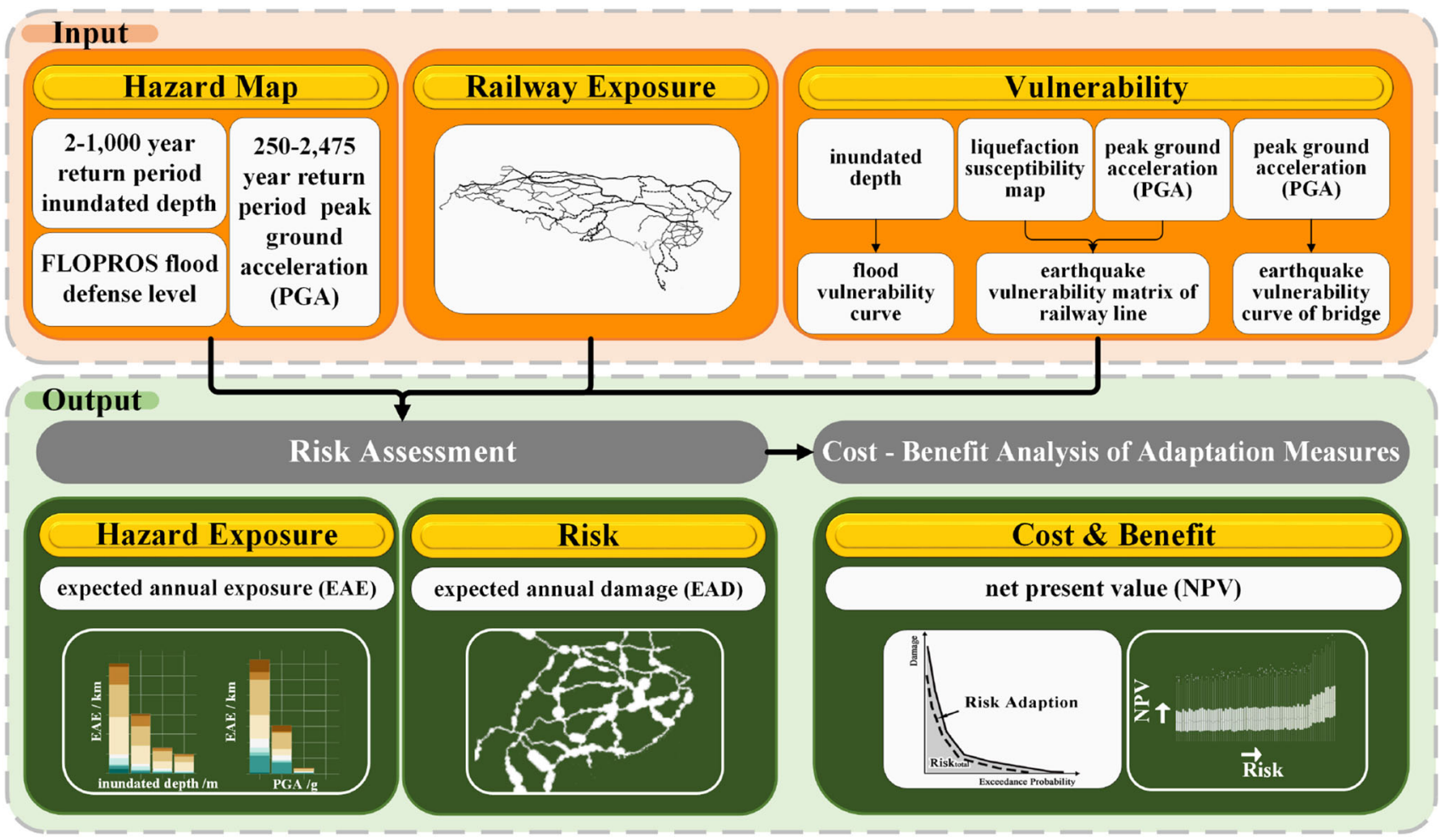

Fig. 2 Research framework of the study on the flood and earthquake risk assessment of railway assets along the Belt and Road 


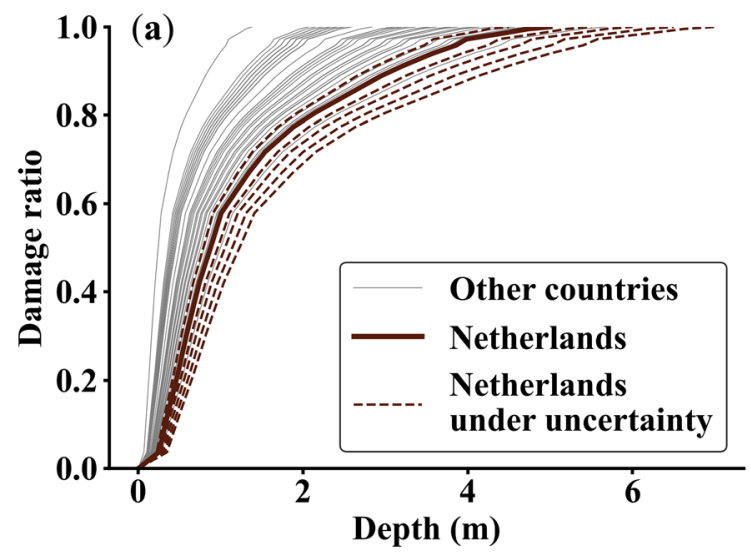

(c)

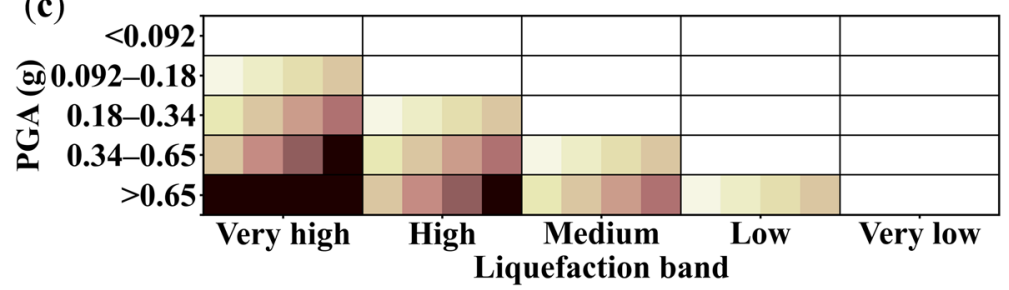

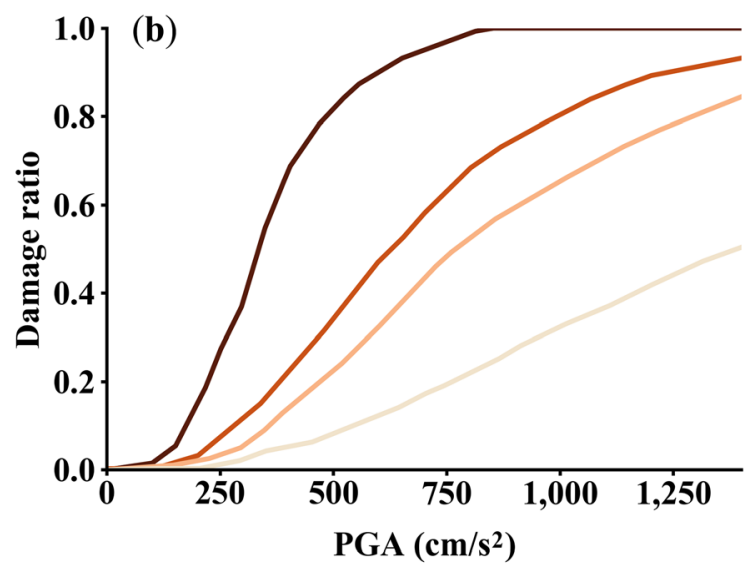

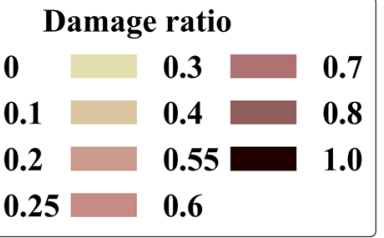

Fig. 3 Vulnerability curves and matrix: a Railway vulnerability to floods; b bridge vulnerability to earthquake shaking - the change in color from dark to light indicates a change in vulnerability from high

According to an earlier survey (Bird and Bommer 2004), serious railway damage from earthquakes is caused by shaking, liquefaction, and landslides. Bridges are mainly threatened by shaking damage, while railway lines are usually damaged by liquefaction, and the effect of landslides in most cases is blocking. Therefore, the risk of shaking is considered for bridges, and the risk of liquefaction is considered for the railway lines in this study. For bridges, we used the vulnerability curves from Koks et al. (2019) (Fig. 3b), which are summarized from Syner-G (Kyriazis et al. 2013). For liquefaction, we used the vulnerability matrix determined by the liquefaction susceptibility band and PGA level (see Sect. 2.1), which was obtained from Koks et al. (2019) (Fig. 3c). The vulnerability curves and matrix both contain four levels of vulnerability from low to high and consider uncertainties, such as the construction time period and structural type.

These damage ratios, obtained through either the vulnerability curves or the vulnerability matrix, were further multiplied by the replacement cost to obtain the economic loss. It is difficult to collect reliable and classified replacement cost data for every country. For railway lines, we collected the construction cost data for Europe and China from existing studies. The cost in Europe is provided by the European Commission and $\mathrm{PwC}$ (Pricewaterhouse Coopers) (Attinà et al. 2018) and is estimated based on the construction costs of new lines in eight European countries. Replacement cost in China is provided by the World Bank to low; c railway damage ratio to liquefaction. Note PGA, peak ground acceleration

(Ollivier et al. 2014) and is estimated based on the construction costs of six projects in China. We used the cost data of conventional railway lines with a speed under $200 \mathrm{~km} / \mathrm{h}$ and removed the cost of land acquisition. Then, we used the global construction cost index to translate the above costs for other different countries, as given by Eq. 2; $\alpha$ is the correction factor determined by Eq. 3:

Cost $_{i}=\alpha \cdot \frac{C C I_{i}}{C I_{\text {China }}} \cdot$ Cost $_{\text {China }}$

$\alpha=\frac{\operatorname{Cost}_{E U} \cdot C C I_{\text {China }}}{\text { CCI }_{E U} \cdot \text { Cost }_{\text {China }}}$

where $\operatorname{Cost}_{i}, \operatorname{Cost}_{E U}$, and Cost $_{\text {China }}$ are the costs in country $i$, Europe, and China, and $C C I_{i}$ and $C C I_{\text {China }}$ are the Construction Cost Indices $(C C I)$ of country $i$ and China. The $C C I$ data are obtained from ARCADIS (2014), which provides a range of construction cost indices at the global scale. The CCI represents the engineering design specification level, labor cost level, and material cost level of different countries. For countries lacking data, we took the mean of countries with the same development level.

For bridges, we used the cost data of China and collected bridge cost data from 20 projects in California (Edwin 2014). We followed a similar approach as presented for regular railway line assets to estimate the bridge construction cost for all the B\&R countries.

Finally, risk was calculated based on the probability of floods/earthquakes and the corresponding loss ratio, that is, 
the trapezoidal area under the exceedance probabilistic curve (Moel and Aerts 2011; Moel et al. 2012; Alfieri et al. 2017), which is expressed by the EAD, as shown in Eq. 4 (Espinet et al. 2018):

$\mathrm{EAD}=1 / 2 \sum_{i=1}^{n}\left(\frac{1}{T_{i}}-\frac{1}{T_{i+1}}\right)\left(D_{i}+D_{i+1}\right)$

where $T_{i}$ is the $i$ th return period, and $D_{i}$ is the damage to the assets corresponding to $T_{i}$, which is equal to the product of the damage ratio and the replacement cost; the unit of $D_{i}$ in this study is U.S. dollars.

We assumed that earthquakes and floods are independent, which is widely adopted by many researchers (Kameshwar and Padgett 2014; Koks et al. 2019). Based on this assumption, we calculated the EAD induced by earthquakes and floods separately and summed them up to obtain a multi-hazard EAD.

To consider the uncertainties in the vulnerability curve/matrix and the replacement cost, the vulnerability curve/matrix and replacement cost parameters were randomly selected to calculate the EAD of each location for 50 repeated processes. For each process, we randomly selected a vulnerability curve/matrix provided in Fig. 3 to consider the uncertainties in the damage ratio. We also randomly selected $C C I$ to consider the uncertainties in the replacement cost. With this approach, we estimated the risk ranges of railway assets.

\subsubsection{Cost-Benefit Analysis of Flood Adaptation}

Risk assessment results are often used to guide adaptation efforts. Based on the above risk assessment results, we chose the segments with the highest risk to perform a costbenefit analysis of flood adaptation measures. To perform the cost-benefit analysis, we needed to set a benefit target. We considered an increase of $10 \% \mathrm{RQI}$ as a strategy to reduce railway vulnerability by upgrading railway flood protection facilities and maintaining regular maintenance. This target value can be adjusted in practice. This concept is expressed more clearly through showing its country equivalent after the increase. The benefit is defined as the avoided EAD. The cost includes the upgrading cost, periodic maintenance cost, and routine maintenance cost. Routine maintenance and periodic maintenance are required to maintain good service conditions of infrastructures. We therefore included maintenance cost in our cost-benefit analysis. We used scenario $o$ to represent the case without investment, and scenario $j$ to indicate the $j$ th investment scenario. The net present value $\left(N P V^{j}\right)$ was calculated by Eq. 5 :
$N P V^{j}=\sum_{y=1}^{20} \frac{E A D^{o}-E A D^{j}-M_{y}^{j}}{(1+d)^{y-1}}-C I^{j}$

where EAD is the expected annual damage; $M_{y}$ is the maintenance cost in the $y$ th year, which is the sum of periodic maintenance costs and routine maintenance costs, expressed by Eq. 6; $d$ is the discount rate; and $C I$ is the upgrading cost, which is expressed by Eq. 7 .

$M_{y}=\left\{\begin{array}{l}k_{1} C \text { when } y=n \\ k_{2} C \text { when } y \neq n\end{array}\right.$

where $C$ is the replacement cost; $k_{1}$ is the routine maintenance cost proportion of the replacement cost; $k_{2}$ is the periodic maintenance cost proportion of the replacement cost; and $n$ is the routine maintenance period.

$C I=k_{3} C$

where $k_{3}$ is the upgrading cost proportion of the replacement cost.

To more succinctly denote the total cost, we introduced the total cost proportion of the replacement cost, $k$, which is calculated by Eq. 8:

$k=\sum_{y=1}^{20} \frac{k_{3 y=1}+k_{2 y \neq n}+k_{1 y=n}}{(1+d)^{y-1}}$

Table 1 gives the range of parameters used in Eq. 5 . Since these parameters are highly uncertain for different countries, we considered a wide range of cost parameters as far as possible to cover the values given by different references (Warusawitharana 2014; Gürlük, 2016; Miyamoto 2019). Within these ranges, we performed a Monte Carlo simulation 1000 times to obtain 1000 adaptation scenarios for each selected railway segment and calculate possible outcomes. For each adaptation scenario, the result was recorded as a positive NPV if the return continued to be greater than the investment within 20 years. The percentage of positive NPV in all adaptation scenarios, $p$, the median NPV value in the 20th year, $m$, and the threshold value of cost proportion, $k$, are taken as indicators for the CBA. We then applied the Morris method (Morris 1991; Campolongo et al. 2007) to analyze the sensitivity of each cost parameter, namely, the contribution of the five parameters in Table 1 to the NPV in the 20th year.

\section{Results}

In this section, we present the exposure and risk of $B \& R$ railways to earthquakes and floods, including the expected annual exposure under different hazard levels and the multi-hazard expected annual damage. High risk segments 
Table 1 Parameters for the cost-benefit analysis (CBA) of implementing risk adaptation measures for railways along the Belt and Road

\begin{tabular}{llll}
\hline Variable & Symbol & Range & Description \\
\hline $\begin{array}{l}\text { Routine maintenance period } \\
\begin{array}{l}\text { Routine maintenance cost } \\
\text { proportion }\end{array}\end{array}$ & $k_{1}$ & $5-10$ year & $\begin{array}{l}\text { Routine maintenance is assumed to happen every } n \text { year } \\
\text { The ratio of routine maintenance cost to replacement cost }\end{array}$ \\
$\begin{array}{l}\text { Yearly periodic maintenance cost } \\
\text { proportion }\end{array}$ & $k_{2}$ & $0.0001-0.001$ & The ratio of yearly periodic maintenance cost to replacement cost \\
$\begin{array}{l}\text { Upgrading cost proportion } \\
\text { Discount rate }\end{array}$ & $k_{3}$ & $0.01-0.1$ & $\begin{array}{l}\text { The ratio of the cost required to increase the Railway Quality Index (RQI) by 10\% } \\
\text { to the replacement cost } \\
\text { Social discount rate }\end{array}$ \\
\hline
\end{tabular}

were selected for cost-benefit analysis to demonstrate the potential of risk adaptation.

\subsection{Exposure to River Flooding and Earthquakes}

Figure 4 shows the kilometer distribution of the expected annual exposure (EAE) for each income group and region in the railway corridors of the BRI. We found that $9.3 \%$ of railway assets in the selected countries are exposed to a one in 100 year flood event and $22.3 \%$ are exposed to a one in 475 year earthquake event. Overall, upper middle-income countries have the highest EAE due to their large amount of railway assets, accounting for $64.8 \%$ and $65.8 \%$ in flood and earthquake, respectively (Fig. 4a). From the perspective of regional differences, Eastern Europe and East Asia have the largest EAE to floods and earthquakes, accounting for $32.9 \%$ and $32.2 \%$ in flood and earthquake, respectively (Fig. 4b).

\subsection{Vulnerability and Risk}

The total expected annual damage (EAD) for river floods and earthquakes is estimated at USD 1,438 (between 966 and 2,026) million. The median EAD distribution of railway assets along the B\&R is presented in Fig. 5 . Approximately $96 \%$ of the EAD is caused by river flooding, and $4 \%$ is caused by earthquakes.

High-risk areas are mostly found in the south-east coastal areas and the south of the B\&R. East Asia, Eastern Europe, and Southeast Asia are the regions that experience the highest risk, accounting for $28 \%, 26 \%$, and $14 \%$ of the total EAD, respectively, which is consistent with the exposure analysis. The countries that have the greatest high local risk (grid cells of $1 \mathrm{~km} \times 1 \mathrm{~km}$ with EAD > USD 1 million) are Pakistan (24\% of the grids) and Myanmar (14\% of the grids), followed by Vietnam (10\%), Lao People's Democratic Republic (10\%), Syria (8\%), Uzbekistan (7\%), and China (6\%). The countries with the greatest moderate local risk (EAD of USD 0.5-1 million) are China
(33\% of the grids) and Pakistan (9\% of the grids). The countries with the lowest risk (EAD less than USD 0.1 million) are Russia (25\%) and China (15\%).

For the newly built and planned projects, the ChinaIndochina Peninsula Economic Corridor, the China-Pakistan Economic Corridor, and the China-Central Asia-West Asia Economic Corridor have the highest absolute risk, with the EAD reaching USD 95, 67, and 40 million, respectively. The China-Indochina Peninsula Economic Corridor, the China-Pakistan Economic Corridor, and the New Eurasian Land Bridge have the highest EAD per km, with an average EAD per $\mathrm{km}$ of USD 18, 17, and 15 thousand, respectively.

Figures 6 and 7 present the risk for each income group and country. From the median value, high-income countries only bear approximately $13.3 \%$ of the flood risk (1.61\% EAE), upper middle-income countries bear 53.3\% $(1.06 \%$ EAE), and lower middle-income countries and lowincome countries bear $33.4 \%$ (1.05\% EAE, on average). High-income countries bear approximately $24.6 \%(0.14 \%$ EAE) of the earthquake risk, upper middle-income countries bear $45.8 \%$ ( $0.38 \%$ EAE), and lower middle-income countries and low-income countries bear $29.6 \%(0.31 \%$ EAE, on average) (Fig. 6a).

We further analyzed the EAD per $\mathrm{km}$, as shown in Fig. $6 \mathrm{~b}$. The EAD per km decreases with increasing income level. Low-income countries show a high degree of vulnerability, with the highest loss proportion due to poor rail quality and low levels of protection from floods. Lower middle-income countries bear relatively more earthquake risk.

Figure 7 presents the top 10 countries at high risk. China and Russia are the two countries with the highest absolute flood risks due to the large exposure of railway assets, whose EAD reaches USD 233-442 and 176-327 million, respectively (Fig. 7a). China and Italy have the highest absolute earthquake risks, with the EAD reaching USD 7-83 and 4-40 million, respectively (Fig. 7a). With respect to EAD per km, Laos and Cambodia have the highest flood 

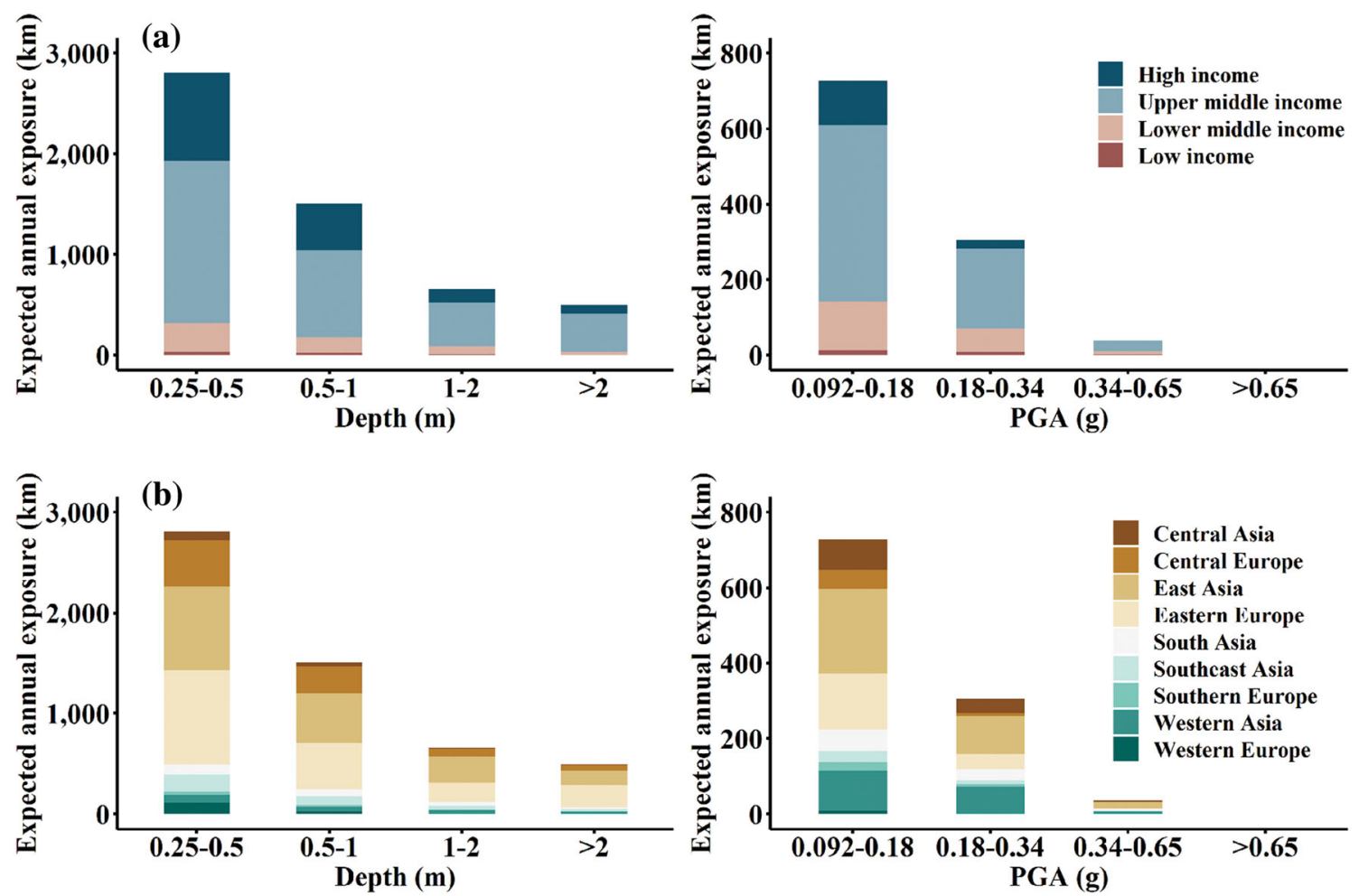

Fig. 4 Distribution of expected annual exposure (EAE) to floods and earthquakes of: a country groups of different income levels; and $\mathbf{b}$ different regions in Asia and Europe related to the railway corridors of the Belt and Road project. Note PGA, peak ground acceleration

risks (USD 66,125-112,154 and 31,954-56,844 per km, respectively) (Fig. 7b). Italy and Myanmar have the highest earthquake EAD per $\mathrm{km}$, with the estimated EAD reaching USD 1,000-3,057 and 893-3,019 per km, respectively. In terms of the proportion of risk to GDP, lower middle-income and low-income countries are the main risk bearers (Fig. 7c). Laos, Cambodia, and Myanmar face the greatest financial burden due to floods, with $0.05-0.2 \%$ of GDP annually. Myanmar and Turkmenistan have the greatest financial burden due to earthquakes, with $0.001-0.045 \%$ of GDP annually. Compared with flood risk, earthquake risk poses a much smaller financial burden, with an absolute EAD about 10 times less and an EAD per $\mathrm{km}$ about 40 times less than those for floods. Most countries at high earthquake risk do not also have a high flood risk. However, countries with dual risk do exist, for example, Myanmar and China.

\subsection{Cost-Benefit Analysis of Adaptation}

To assess the benefits of adaptation, we selected grid cells with a high local risk (EAD per km larger than USD 0.5 million). A total of 235 grids across 10 countries were selected. To help understand the vulnerability reduction concept of the $10 \%$ increase in RQI, Table 2 provides the best analogy for the countries selected after an increase of $10 \%$ RQI.

Two risk levels are classified as given in Table 3, including regions $\mathrm{A}$ and $\mathrm{B}$, where $\mathrm{A}$ contains the segments with an EAD larger than USD 0.5 but less than 0.7 million per $\mathrm{km}$, and B contains segments with an EAD larger than USD 0.7 million per $\mathrm{km}$.

With the increase in risk, more adaptation scenarios can support NPV becoming positive (Fig. 8b), with the average value of $p$ increasing from $51.7 \%$ (A) to $86.2 \%$ (B). Figure 8a presents the NPV results of these segments in the 20th year. The NPV value shows an upward trend when it goes from railway segments with lower risk to those with higher risk. The average median value of $m$ of the 1,000 adaptation scenarios increases from USD 0.13 (A) to USD 0.27 (B) million.

Figure 9a presents the distribution of $k$ of one randomly selected grid, and a similar pattern exists for other grids. When $k$ is less than $k_{a}$, all adaptation scenarios support positive NPV, and when $k$ is greater than $k_{b}$, all adaptation scenarios lead to negative NPV. For $k$ between $k_{a}$ and $k_{b}$, both positive and negative NPV have a chance to occur. As the risk increases, $k_{a}$ and $k_{b}$ move towards the right, that is, the higher the risk, the higher is the acceptable cost threshold $k$ value. The average $k_{a}$ increases from 0.098 (A) to 0.140 (B), and $k_{b}$ increases from 0.135 (A) to 0.194 


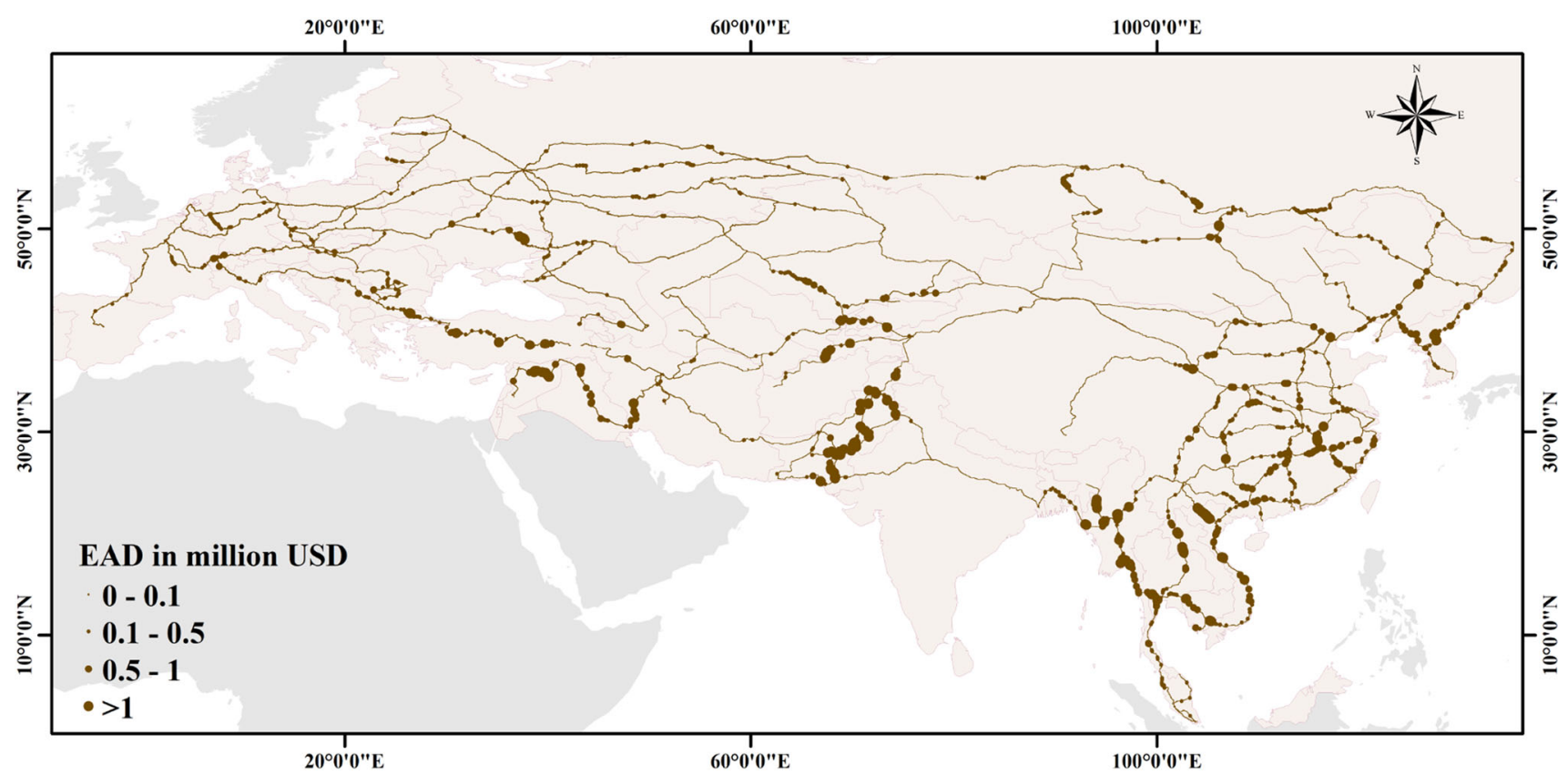

Fig. 5 Distribution of flood and earthquake median risk of railway assets along the Belt and Road. Note EAD, expected annual damage
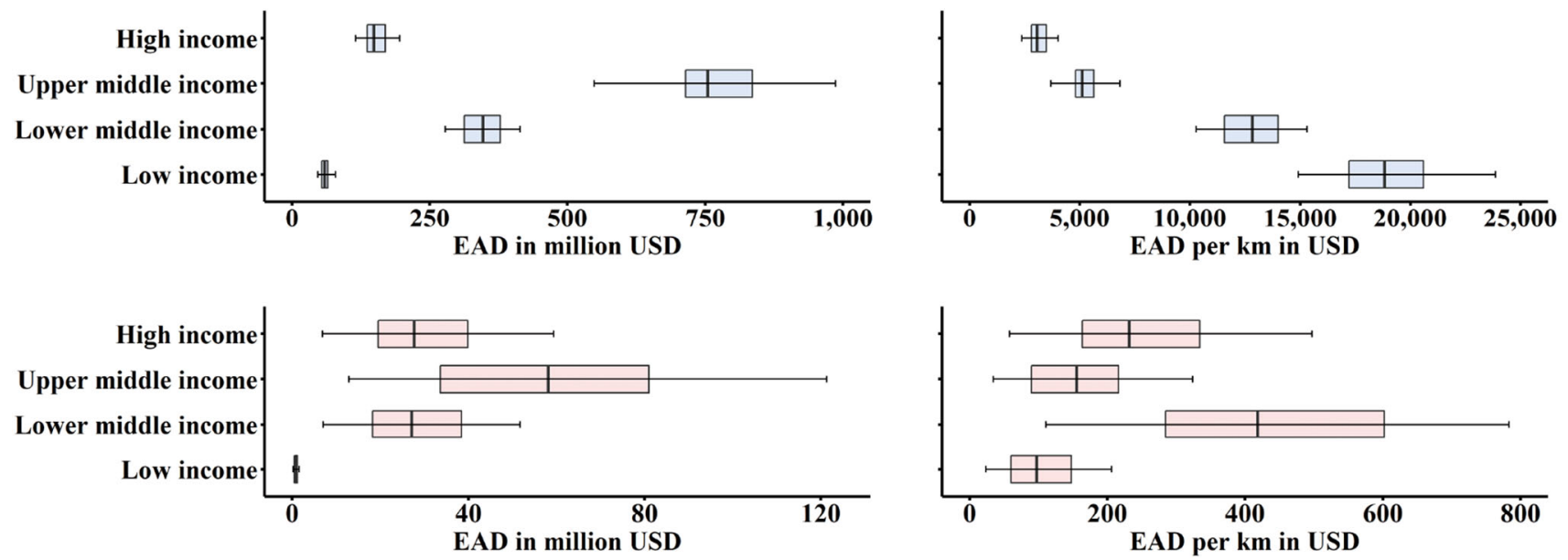

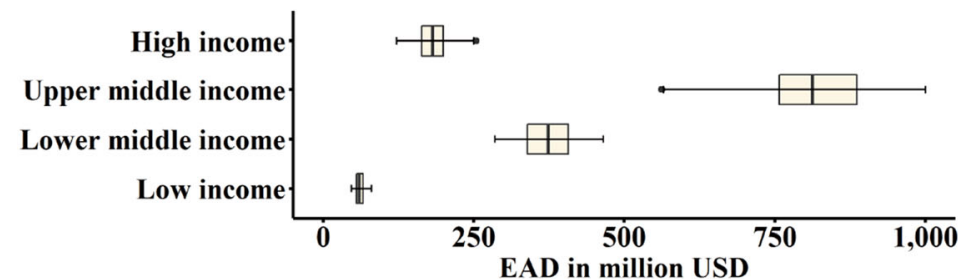

(a)

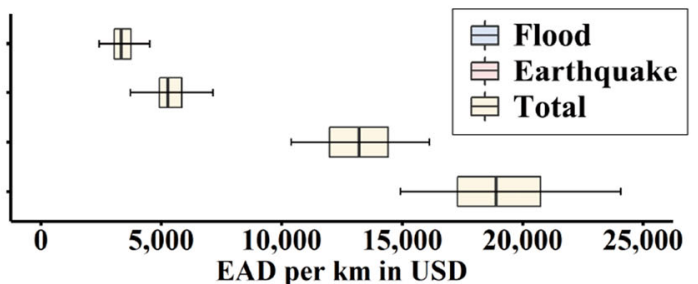

(b)

Fig. 6 Distribution of flood/earthquake/total risk of railway assets along the Belt and Road by: a Absolute risk (expected annual damage, EAD) of the four income groups; $\mathbf{b}$ EAD per $\mathrm{km}$ of the four income groups. Note EAD, expected annual damage

(B) (Table 3). For the design of adaption measures for the selected 235 high-risk railway segments, when the required adaptation cost in 20 years is below $8.4 \%$ of the replacement cost, it will certainly bring positive benefits within 20 years.

The contribution of routine maintenance period $(n)$, routine maintenance cost proportion $\left(k_{1}\right)$, yearly periodic 
Table 2 Country analogy after 10\% Railway Quality Index (RQI) increase

\begin{tabular}{ll}
\hline Country where the Segments Are Located & Country Analogy \\
\hline Myanmar & Bangladesh/Slovenia \\
Cambodia & - \\
Tajikistan & Ukraine \\
Korea, Democratic People's Republic of & Vietnam/Bulgaria/Turkey \\
Lao People's Democratic Republic & Hungary/Poland \\
Pakistan & Hungary/Poland \\
Mongolia & Croatia/Greece/Korea, Democratic People's Republic of \\
Uzbekistan & Malaysia \\
Syria & Bangladesh/Slovenia \\
Kyrgyzstan & Thailand/Romania \\
\hline
\end{tabular}

Table 3 Results of the cost-benefit analysis (range (mean, std)) of adaptation measures to mitigate risks faced by railways

\begin{tabular}{|c|c|c|c|c|}
\hline Risk Classification & $\begin{array}{l}\text { Percentage of NPV }>0 \\
\text { in } 20 \text { Years } p\end{array}$ & $\begin{array}{l}\text { Median NPV in the } \\
\text { 20th Year } m\end{array}$ & $\begin{array}{l}\text { Threshold Value of Total } \\
\text { Cost Proportion } k_{a}\end{array}$ & $\begin{array}{l}\text { Threshold Value of Total } \\
\text { Cost Proportion } k_{b}\end{array}$ \\
\hline \multicolumn{5}{|l|}{ A } \\
\hline $\begin{array}{l}(\mathrm{USD} 0.5<\mathrm{EAD}<\mathrm{USD} 0.7 \\
\text { million per } \mathrm{km})\end{array}$ & $\begin{array}{l}31.7-72.7 \% \\
(51.7 \%, 9.1 \%)\end{array}$ & $\begin{array}{l}0.09-0.18 \\
(0.13,0.02)\end{array}$ & $\begin{array}{l}0.084-0.118 \\
(0.098,0.0085)\end{array}$ & $\begin{array}{l}0.118-0.164 \\
(0.135,0.012)\end{array}$ \\
\hline \multicolumn{5}{|l|}{ B } \\
\hline $\begin{array}{l}(\mathrm{EAD}>\text { USD } 0.7 \text { million per } \\
\quad \mathrm{km})\end{array}$ & $\begin{array}{l}75.8 \%-92.6 \% \\
(86.2 \%, 0.38 \%)\end{array}$ & $\begin{array}{l}0.21-0.33 \\
(0.27,0.04)\end{array}$ & $\begin{array}{l}0.120-0.155 \\
(0.140,0.0099)\end{array}$ & $\begin{array}{l}0.170-0.214 \\
(0.194,0.014 \%)\end{array}$ \\
\hline
\end{tabular}

maintenance cost proportion $\left(k_{2}\right)$, upgrade cost proportion $\left(k_{3}\right)$, and discount rate $(d)$ to NPV in the 20th year is presented in Fig. 9b, and the results show that the contributions of $k_{3}, k_{2}$, and $k_{1}$ reach $24.37 \%, 23.12 \%$, and $23.11 \%$ on average, respectively, followed by the contributions of $d(17.85 \%)$ and $n(11.55 \%)$. That is, the upgrade cost and maintenance cost largely determine NPV, while the routine maintenance period and discount rate are less important.

\section{Discussion}

This study assessed flood and earthquake risks of existing and newly planned railway assets along the B\&R and highlighted the effectiveness and necessity of risk assessment and adaptation. To our knowledge, this is the first study that quantifies the multi-hazard risk faced by railway transportation infrastructure in the B\&R project. Such an analysis helps to identify high-risk routes and design adaption measures for risk mitigation, which can increase government and construction companies' awareness of disaster risk.
To verify our analyzed results, we compared the estimated loss of Chinese railways to floods with the recorded data. According to the Han (2016), the annual average loss of Chinese railways to floods from 2010 to 2016 reached RMB 47 thousand yuan (USD 7.3 thousand) per km, while we estimated RMB 30-68 thousand yuan (USD 4.7-10.6 thousand) per $\mathrm{km}$. Note that this is a rough comparison because of the scarce validation data. Considering that the loss recorded may contain both the pluvial and fluvial flooding damages, our results may have slightly overestimated the risk. Nevertheless, our assessment shows an acceptable credibility.

However, there are still a number of uncertainties that should be addressed. First, there are some uncertainties with the flood hazard map provided by Ward et al. (2017). The resolution is $1 \mathrm{~km}$, and this would bring some errors in the inundation simulation. Furthermore, it only considers major rivers-minor water courses were not consideredwhich may lead to an underestimate of flood risk.

Second, the determination of the vulnerability of infrastructure is challenging. Due to the lack of local vulnerability curves of railway infrastructures, we used a factor correction method to take the regional differences of 

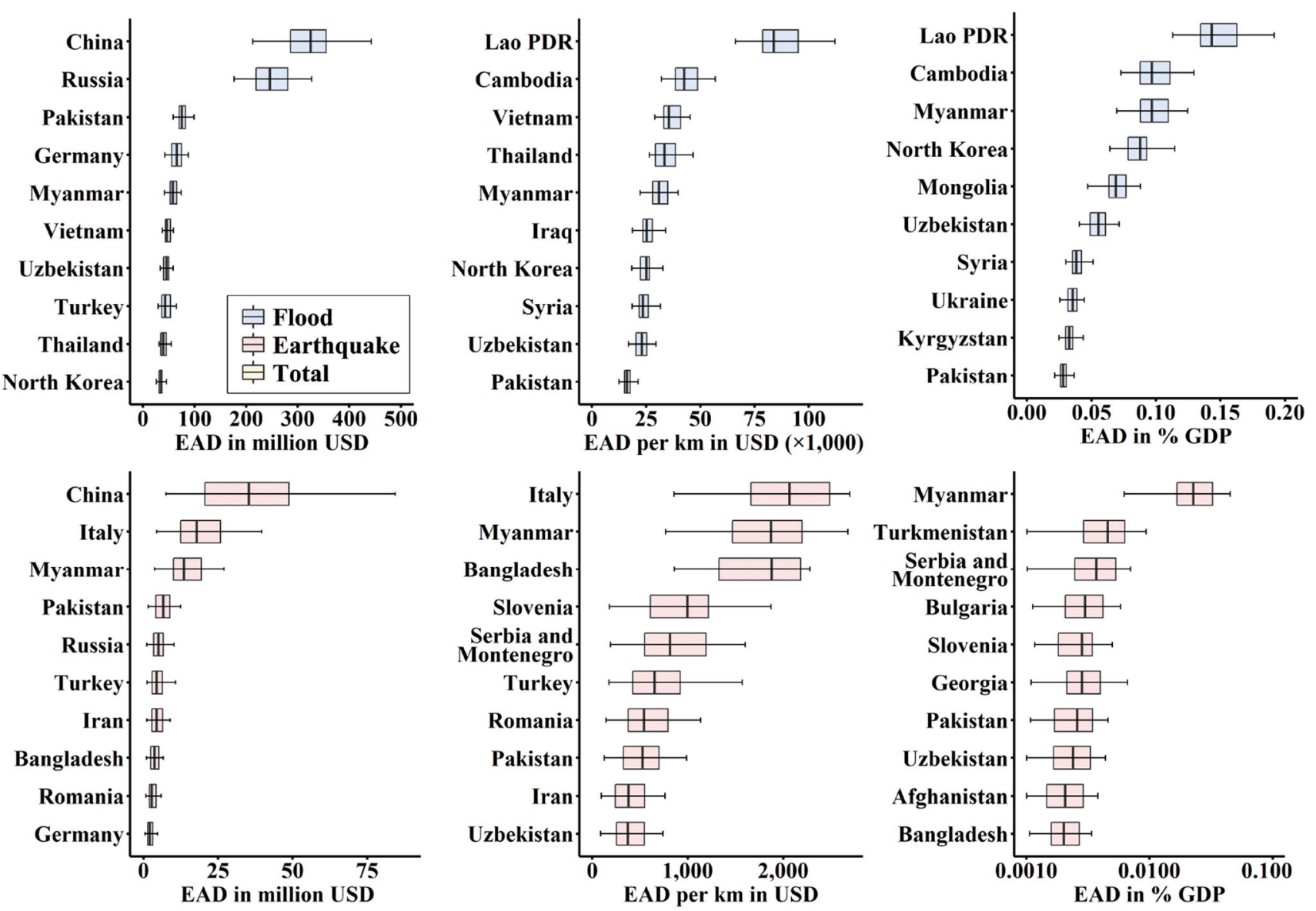

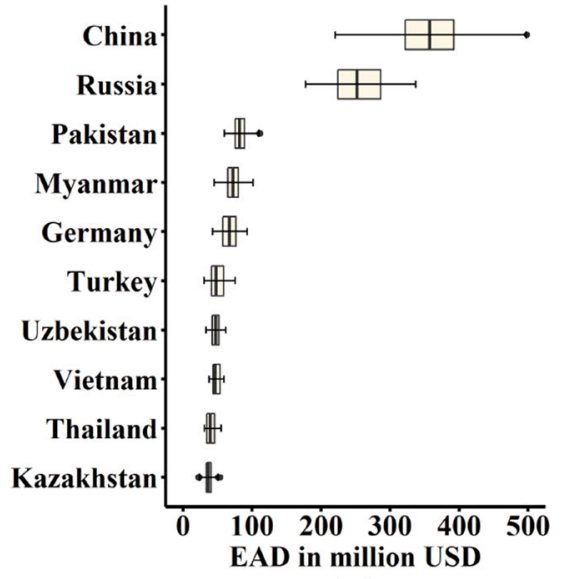

(a)

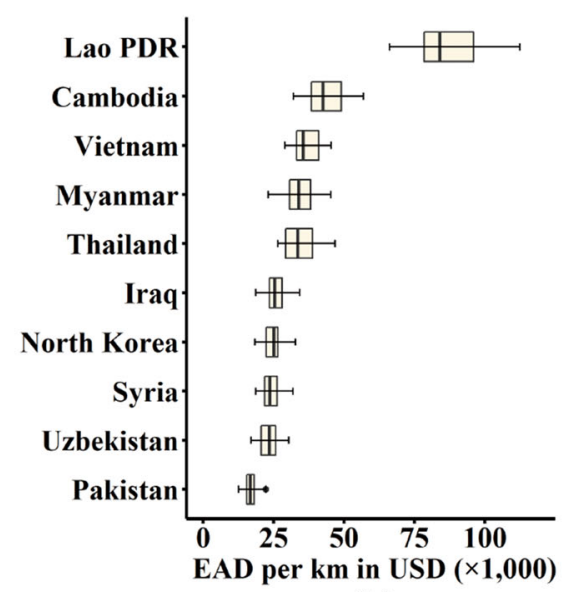

(b)

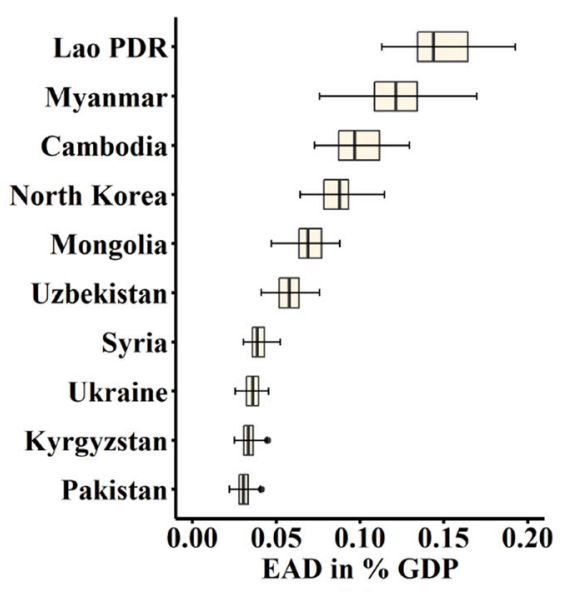

(c)
Fig. 7 Top 10 countries with the highest flood/earthquake/total risk for railway assets along the Belt and Road: a Top 10 countries with the highest absolute risk (expected annual damage, EAD); b Top 10

vulnerability into account. However, the RQI is not a uniform value in a country. Interventions such as building viaducts or deep foundation systems may be implemented in some segments due to complex geological and hydrological conditions, which would increase the local RQI, countries with the highest EAD per km; c Top 10 countries with the highest risk share of GDP

while some adverse factors may decrease the local RQI. Some geological phenomena, for example, as well as some anthropogenic factors result in a rise of soil saturation or soil loosening, making the railway subgrade more vulnerable to flood damage (Moran et al. 2010; Tsubaki et al. 
Fig. 8 The percentage of positive net present value (NPV) in all adaptation scenarios and median NPV value in the 20th year at each grid: a NPV in the 20th year of different risk regions;

b Percentage of positive results in 1000 outcomes. Note EAD, expected annual damage

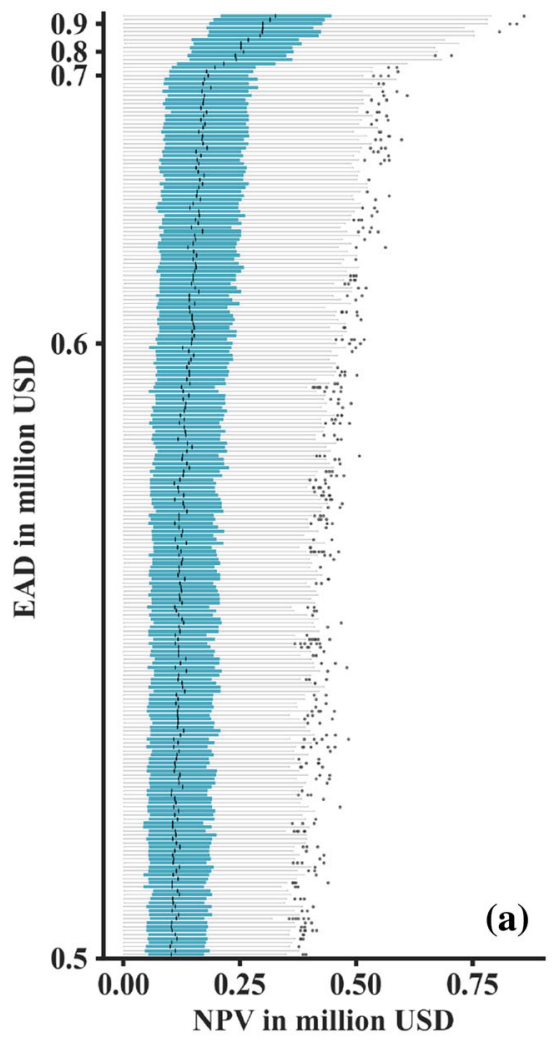

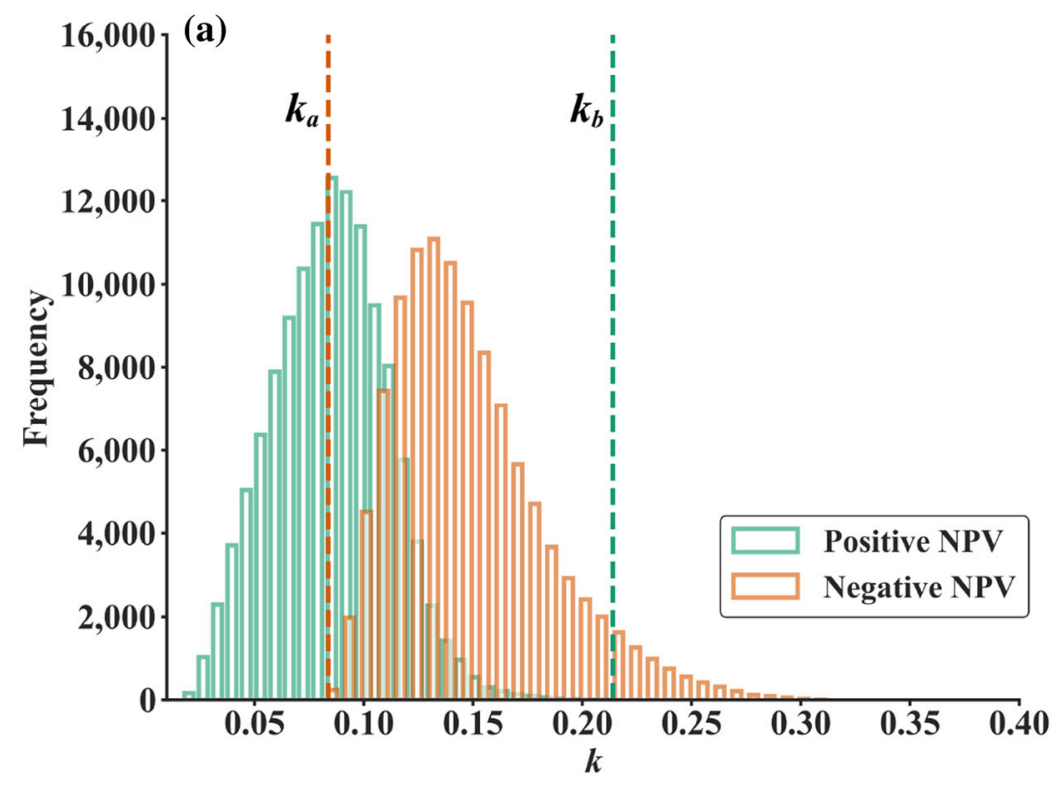

(b)

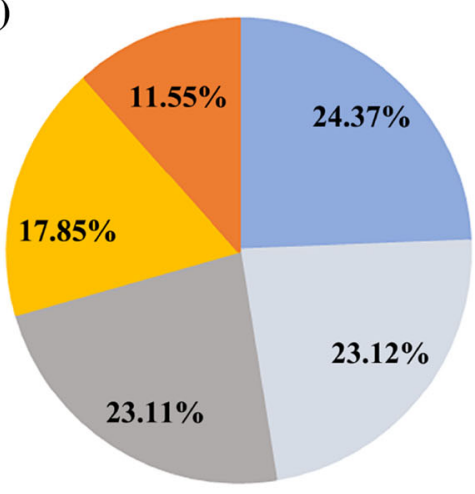

Upgrade cost proportion $\left(k_{3}\right)$

Yearly periodic maintenance cost proportion $\left(k_{2}\right)$

Routine maintenance cost proportion $\left(k_{1}\right)$

Discount rate $(d)$

Routine maintenance period $(n)$

Fig. 9 The impact of total cost proportion $k$ on net present value (NPV). a Distribution of NPV to the total cost proportion, $k$; $\mathbf{b}$ The contribution of each factor to $k$

2016; Lagadec et al. 2018). The risk assessment results would be more robust if the vulnerability curves of the railway infrastructure for different countries were available, which would require the joint efforts of the academic community.
Third, the determination of replacement costs also presents significant uncertainties, given a large range and regional differences. Many existing public cost data often contain the project indirect cost, such as land acquisition at high density urban areas. It is difficult to remove the 
indirect cost during construction for all countries. The factor correction method used in this study is carried out at the country level and neglects local specific influencing factors on the cost.

Fourth, cost-benefit analysis of adaptation measures is interesting but also very challenging. It is difficult to estimate the cost of raising the RQI by $10 \%$ for different lines. We provided a wide variety of cost-benefit analysis parameter combinations and introduced the concept of cost threshold. We used the same maintenance or upgrading cost range for each country and did not take the difference of cost parameters between different countries into account. Moreover, the range of cost parameters we used in this study may be insufficient to cover the costs for some projects.

Some other limitations also exist for this study. First, high flood velocity would bring additional force that creates a greater risk for infrastructures. Kreibich et al. (2009) provided the relationship between velocity and damage, and emphasized the importance of velocity on road infrastructure. The empirical velocity-damage model was also developed based on event investigation (Kellermann et al. 2015). As velocity is not available from the flood dataset used, we did not take the effect of velocity into account. Further work can be performed in this direction.

Second, we did not consider the effect of climate change and assumed that the EAD would remain constant in the future for the cost-benefit analysis. However, climate change may lead to more intense and more frequent flooding along the B\&R. Hirabayashi et al. (2013) incorporated future climate ensemble data into the global river routing model, and the results indicated that the frequency of floods in Southeast Asia and the Indian Peninsula would increase significantly. Alfieri et al. (2017) assessed global flood risk to the economy and the population, where Asia, the United States, and Europe would experience the greatest increases in flood risk. Future work can be performed to assess the risk of infrastructure in the $\mathrm{B} \& \mathrm{R}$ countries considering climate change effects.

Third, our approach only considers the physical damage to railway infrastructures. The loss of transportation interruption due to damage is not assessed, and the indirect benefits of reducing disaster risk are not included in the cost-benefit analysis. A World Bank study for roads in Mozambique (Espinet et al. 2018), for example, indicated that the user benefits brought by adaption measures are equal to or greater than the reduced physical damage costs. The benefit from disaster risk adaptation would be greater considering future rising flood risk and increased international trade.

\section{Conclusion}

This study assesses the existing and planned railway asset risk with respect to two major natural hazards-river floods and earthquakes-among 50 countries along the B\&R, which contributes to closing the gap of multi-hazard risk assessment faced by transportation infrastructure along the B\&R. Through a cost-benefit analysis of physical adaptation measures in high-risk areas, we exemplify the applicability and usability of this risk assessment. The main conclusions are as follows:

1. We found that $9.3 \%$ of railway assets in the selected $\mathrm{B} \& \mathrm{R}$ countries are exposed to a one in 100 year flood event, and $22.3 \%$ are exposed to a one in 475 year earthquake event. High-income countries (1.61\%) have the highest exposure per $\mathrm{km}$ to flood hazards, while upper middle $(0.38 \%)$ and lower middle-income countries $(0.37 \%)$ have the highest exposure to earthquake hazards. From the perspective of regional differences, Southeast Asia (2.58\%) and Western Asia $(0.87 \%)$ are the regions that experience the highest flood and earthquake hazard exposure to railway assets per $\mathrm{km}$.

2. The EAD of all railway assets along the $B \& R$ is estimated at USD 1,438 (between 966 and 2,026) million. Among them, floods constitute the majority (96\%). Earthquake risk is much smaller due to its low probability of occurrence. Regionally, East Asia (28\%), Eastern Europe (26\%), and Southeast Asia (14\%) are the regions that experience the highest risk. At the national scale, with respect to both flood and earthquake hazards, China has the highest EAD (between USD 240 and 525 million in total). Russia follows China in terms of the EAD (between USD 176 and 327 million) due to floods, and Italy comes after China in EAD (between USD 4 and 40 million) due to earthquakes. Laos and Cambodia are the two countries with the highest EAD per $\mathrm{km}$ due to flooding (USD 66,125-112,154 and USD 31,954-56,844 per km), while Italy and Myanmar have the highest earthquake EAD per km (USD 1,000-3,057 and USD 893-3,019 per km). For the newly built and planned projects, the China-Indochina Peninsula Economic Corridor, the China-Pakistan Economic Corridor, and the ChinaCentral Asia-West Asia Economic Corridor are in the zones with the highest absolute risk, with average EADs of USD 95, 67, and 40 million, respectively. The China-Indochina Peninsula Economic Corridor, China-Pakistan Economic Corridor, and the New Eurasian Land Bridge have the highest EAD per km, and the average EAD per $\mathrm{km}$ is USD 18, 17, and 15 thousand per $\mathrm{km}$, respectively. 
3. We performed a CBA to evaluate the benefit of increasing the railway quality index (RQI) by $10 \%$ to mitigate flood risk. The results show that a large benefit can be gained for railway segments with higher risk. For railway segments with an EAD larger than USD 0.7 million per $\mathrm{km}, 75.8-92.6 \%$ of 1,000 adaptation scenarios support positive NPV in 20 years. Our sensitivity analysis further revealed that upgrading and maintenance costs contribute most to NPV, while the routine maintenance period is relatively less important. That is, NPV can be more effectively increased by reducing the cost of upgrades and maintenance.

Acknowledgements This work was supported by the National Natural Science Foundation of China (Grant Number 41771538) and the National Key Research and Development Plan (Grant Number 2017YFC1502901). The financial support is highly appreciated.

Open Access This article is licensed under a Creative Commons Attribution 4.0 International License, which permits use, sharing, adaptation, distribution and reproduction in any medium or format, as long as you give appropriate credit to the original author(s) and the source, provide a link to the Creative Commons licence, and indicate if changes were made. The images or other third party material in this article are included in the article's Creative Commons licence, unless indicated otherwise in a credit line to the material. If material is not included in the article's Creative Commons licence and your intended use is not permitted by statutory regulation or exceeds the permitted use, you will need to obtain permission directly from the copyright holder. To view a copy of this licence, visit http://creativecommons. org/licenses/by/4.0/.

\section{References}

Alfieri, L., B. Bisselink, F. Dottori, G. Naumann, A. de Roo, P. Salamon, K. Wyser, and L. Feyen. 2017. Global projections of river flood risk in a warmer world. Earth's Future 5(2): 171-182.

ARCADIS. 2014. International construction cost report: What will it mean for 2015. Amsterdam, The Netherlands: ARCADIS.

Attinà, M., A. Basilico, M. Botta, I. Brancatello, F. Gargani, V. Gori, F. Wilhelm, and M. Menting et al. 2018. Assessment of unit costs (standard prices) of rail projects (CAPital EXpenditure). Luxembourg: Publications Office of the European Union.

Bach, C., A.K. Gupta, S.S. Nair, and J. Birkmann. 2013. Critical infrastructures and disaster risk reduction. New Delhi: National Institute of Disaster Management and Deutsche Gesellschaft für Internationale Zusammenarbeit (GIZ).

Bird, J.F., and J.J. Bommer. 2004. Earthquake losses due to ground failure. Engineering Geology 75(2): 147-179.

Campolongo, F., J. Cariboni, and A. Saltelli. 2007. An effective screening design for sensitivity analysis of large models. Environmental Modelling \& Software 22(10): 1509-1518.

Chai, D., M. Wang, and K. Liu. 2020. Driving factors of natural disasters in Belt and Road countries. International Journal of Disaster Risk Reduction 51: 101774.

CIMNE (Centro Internacional de Métodos Numéricos en Ingeniería) and INGENIAR (Ingeniería para el Análisis del Riesgo Ingenieros Consultores). 2015. Update on the probabilistic modelling of natural risks at global level: Global risk model.
Background paper. Prepared for the 2015 Global Assessment Report on Disaster Risk Reduction. Barcelona, Spain and Bogotá, Colombia: CIMNE and INGENIAR.

Cui, P., A.D. Regmi, Q. Zou, L. Yu, X.Q. Chen, and D.Q. Cheng. 2017. Natural hazards and disaster risk in One Belt One Road corridors. In Proceedings of the Workshop on World Landslide Forum 2017: Advancing Culture of Living with Landslides, ed. M. Mikos, B. Tiwari, Y. Yin, and K. Sassa, 1155-1164. Heidelberg: Springer.

De Bruijn, K., D. Wagenaar, K. Slager, M. de Bel, and A. Burzel. 2015. Updated and improved method for flood damage assessment: SSM2015 (version 2). Delft, The Netherlands: Deltares, 2015.

de Moel, H., and J. Aerts. 2011. Effect of uncertainty in land use, damage models and inundation depth on flood damage estimates. Natural Hazards 58(1): 407-425.

de Moel, H., N. Asselman, and J. Aerts. 2012. Uncertainty and sensitivity analysis of coastal flood damage estimates in the west of the Netherlands. Natural Hazards and Earth System Sciences 12(4): 1045-1058.

Edwin. 2014. Bridges and viaducts. Hot Rails, 8 September 2014. hotrails.net/2014/09/bridges_and_viaducts/. Accessed 29 Aug 2020.

Espinet, X., J. Rozenberg, K.S. Rao, and S. Ogita. 2018. Piloting the use of network analysis and decision-making under uncertainty in transport operations: Preparation and appraisal of a rural roads project in Mozambique under changing flood risk and other deep uncertainties. World Bank Policy Research Working Paper 8490. Washington, DC: World Bank Group.

Feyen, L., R. Dankers, K. Bódis, P. Salamon, and J.I. Barredo. 2012. Fluvial flood risk in Europe in present and future climates. Climatic Change 112(1): 47-62.

Gürlük, S. 2016. Diagnostic of high social discount rate in developing countries and low social discount rate in developed countries. In Advances in environmental research, vol 49, ed. J.A. Daniels, 129-140. Hauppauge, NY: Nova Science Publishers.

Han, J., ed. 2016. In China railway yearbook. Beijing: China Railway Publishing House (in Chinese).

Helsingsen, H., B. Milligan, M. Dailey, and N. Bhagabati. 2018. Greening China's Belt and Road initiative in Myanmar: Rapid assessment of opportunities and risks for Myanmar's natural capital. Myanmar: WWF (World Wide Fund for Nature). https:// www.wwf.org.mm/en/news_room/publications/?uNewsID= 318715. Accessed 29 Sept 2020.

Hirabayashi, Y., R. Mahendran, S. Koirala, L. Konoshima, D. Yamazaki, S. Watanabe, H. Kim, and S. Kanae. 2013. Global flood risk under climate change. Nature Climate Change 3(9): 816-821.

Kameshwar, S., and J.E. Padgett. 2014. Multi-hazard risk assessment of highway bridges subjected to earthquake and hurricane hazards. Engineering Structures 78: 154-166.

Kellermann, P., A. Schöbel, G. Kundela, and A.H. Thieken. 2015. Estimating flood damage to railway infrastructure-The case study of the March River flood in 2006 at the Austrian Northern Railway. Natural Hazards and Earth System Sciences 15(11): 2485-2496.

Khan, A., Y. Chenggang, G. Khan, and F. Muhammad. 2020. The dilemma of natural disasters: Impact on economy, fiscal position, and foreign direct investment alongside Belt and Road initiative countries. Science of the Total Environment 743: Article 140578.

Koks, E.E., B. Jongman, T.G. Husby, and W.J.W. Botzen. 2015. Combining hazard, exposure and social vulnerability to provide lessons for flood risk management. Environmental Science \& Policy 47: 42-52.

Koks, E.E., J. Rozenberg, C. Zorn, M. Tariverdi, M. Vousdoukas, S. Fraser, J. Hall, and S. Hallegatte. 2019. A global multi-hazard 
risk analysis of road and railway infrastructure assets. Nature Communications 10: Article 2677.

Kreibich, H., K. Piroth, I. Seifert, H. Maiwald, U. Kunert, J. Schwarz, B. Merz, and A.H. Thieken. 2009. Is flow velocity a significant parameter in flood damage modelling?. Natural Hazards and Earth System Sciences 9(5): 1679-1692.

Kyriazis, P., A. Sotiris, K. Kalliopi, C. Helen, and T. Fabio. 2013. Systemic seismic vulnerability and risk analysis for buildings, lifeline networks and infrastructures safety gain. SYNER-G synthetic document. Luxembourg: Joint Research Centre, European Commission.

Lagadec, L.-R., L. Moulin, I. Braud, B. Chazelle, and P. Breil. 2018. A surface runoff mapping method for optimizing risk assessment on railways. Safety Science 110(Part B): 253-267.

Mao, X.Z., J. Liu, T. Li, and H. Qiu. 2018. Spatio-temporal patterns of natural disasters in countries along the Belt and Road. Journal of Natural Disasters 27(1): 1-8 (in Chinese).

Miyamoto. 2019. Overview of engineering options for increasing infrastructure resilience: Final Report. Washington, DC: World Bank Group. https://documents.worldbank.org/en/publication/ documents-reports/documentdetail/474111560527161937/finalreport. Accessed 30 Jul 2020.

Moran, A.P., A.H. Thieken, A. Schöbel, and C. Rachoy. 2010. Documentation of flood damage on railway infrastructure. In Data and mobility, ed. J. Düh, H. Hufnagl, E. Juritsch, R. Pfliegl, H.-K. Schimany, and H. Schönegger, 61-70. Heidelberg: Springer.

Morris, M.D. 1991. Factorial sampling plans for preliminary computational experiments. Technometrics 33(1): 161-174.

NDRC (National Development and Reform Commission) and NRA (National Railway Administration of the People's Republic of China). 2016. China Railway Express construction and development plan (2016-2020). Beijing: National Railway Administration of the People's Republic of China (in Chinese).

Ollivier, G., J. Sondhi, and N. Zhou. 2014. High-speed railways in China: A look at construction costs. China Transport Topics No. 9. Beijing: World Bank.

PICC (The People's Insurance Company [Group] of China). 2014. Internal report of PICC. Beijing: PICC (in Chinese).

Refinitiv. 2020. BRI connect: The numbers behind the Belt and Road initiative. Amman, Jordan: Refinitiv. https https://mp.weixin.qq. com/s/o1dLPVAd0Jbe2zWBm9K-IA. Accessed 30 Sept 2020.

Scawthorn, C., P. Flores, N. Blais, H. Seligson, E. Tate, S. Chang, E. Mifflin, and W. Thomas et al. 2006. HAZUS-MH flood loss estimation methodology. II. Damage and loss assessment. Natural Hazards Review 7: 72-81.

Schwab, K., X. Sala-i-Martín, and R. Samans. 2017. The global competitiveness report 2017-2018. Geneva: World Economic Forum.

Scussolini, P., J.C.J.H. Aerts, B. Jongman, L.M. Bouwer, H.C. Winsemius, H. de Moel, and P.J. Ward. 2016. FLOPROS: An evolving global database of flood protection standards. Natural Hazards and Earth System Sciences 16(5): 1049-1061.

Tsubaki, R., J.D. Bricker, K. Ichii, and Y. Kawahara. 2016. Development of fragility curves for railway embankment and ballast scour due to overtopping flood flow. Natural Hazards and Earth System Sciences 16(12): 2455-2472.

Wang, C., X. Wu, and L. Zhou. 2018. Analysis of associated economic loss of meteorological disasters among the Belt and Road Typical Countries-Taking the China's Typhoon Rammasun in 2014 as an example. In Proceedings of the 8th Annual Meeting of Risk Analysis Council of China Association for Disaster Prevention, 20-21 October 2018, Xi'an, China, 198-204. Dordrecht, The Netherlands: Atlantis Press.

Ward, P.J., B. Jongman, J.C. Aerts, P.D. Bates, W.J. Botzen, A.D Loaiza, S. Hallegatte, and J.M. Kind et al. 2017. A global framework for future costs and benefits of river-flood protection in urban areas. Nature Climate Change 7(9): 642-646.

Ward, P.J., B. Jongman, F.S. Weiland, A. Bouwman, R. van Beek, M.F. Bierkens, W. Ligtvoet, and H.C. Winsemius. 2013. Assessing flood risk at the global scale: Model setup, results, and sensitivity. Environmental Research Letters 8(4): 044019.

Warusawitharana, M. 2014. The social discount rate in developing countries. Washington, DC: Board of Governors of the Federal Reserve System (US).

Winsemius, H., L. Van Beek, B. Jongman, P. Ward, and A. Bouwman. 2013. A framework for global river flood risk assessments. Hydrology and Earth System Sciences 17(5): 1871-1892.

Winsemius, H.C., J.C. Aerts, L.P. Van Beek, M.F. Bierkens, A. Bouwman, B. Jongman, J.C. Kwadijk, and W. Ligtvoet et al. 2016. Global drivers of future river flood risk. Nature Climate Change 6(4): 381-385.

Worden, C.B., D.J. Wald, J. Sanborn, and E.M. Thompson. 2015. Development of an open-source hybrid global Vs30 model. In Proceedings of the Seismological Society of America 2015 Annual Meeting, 21-23 April 2015, Pasadena, California, USA. https://www.usgs.gov/natural-hazards/earthquake-hazards/ science/vs30-models-and-data?qt-science_center_objects=0\#qtscience_center_objects. Accessed 30 Sept 2020.

World Bank. 2019. Belt and Road economics: Opportunities and risks of transport corridors. Washington, DC: World Bank.

$\mathrm{Wu}, \mathrm{R} .2019$. The risks and prevention of China's railway "going global" - Based on Mombasa Nairobi Railway. Beijing: Beijing Jiaotong University (in Chinese).

Xi, P., and W. Liu. 2017. Ancient and modern silk road: Panoramic map of the Belt and Road initiative. Beijing: Sinomap Press (in Chinese).

Yu, L., P. Cui, A.D. Regmi, V. Murray, A. Pasuto, G. Titti, and M. Shafique. 2018. An international program on Silk Road Disaster Risk Reduction-A Belt and Road initiative (2016-2020). Journal of Mountain Science 15(4): 1383-1396.

Yu, X., X. Yu, C. Li, and Z. Ji. 2020. Information diffusion-based risk assessment of natural disasters along the silk road economic belt in China. Journal of Cleaner Production 244: 118744.

Zhu, J., L.G. Baise, and E.M. Thompson. 2017. An updated Geospatial Liquefaction Model for global application. Bulletin of the Seismological Society of America 107(3): 1365-1385.

Zorn, C., and E. Koks. 2019. Global liquefaction susceptibility map. https://doi.org/10.5281/zenodo.2583746. Accessed 30 May 2020. 